\title{
EVALUASI EFEKTIVITAS SISTEM PENGENDALIAN INTERNAL DALAM PROSEDUR HIBAH PADA SATUAN KERJA KANTOR WILAYAH KEMENTERIAN AGAMA PROVINSI SULAWESI UTARA
}

\author{
Nazlia Djakaria $^{1}$, Ventje Ilat $^{2}$, Natalia Gerungai ${ }^{3}$ \\ ${ }^{1,2,3}$ Jurusan Akuntansi, Fakultas Ekonomi dan Bisnis, Universitas Sam Ratulangi, Jl. Kampus Bahu, Manado, \\ 95115, Indonesia \\ E-mail : nanazdjakaria@gmail.com
}

\begin{abstract}
Internal Control System is a system of business or social system that the company consists of organizational structure, methods and measures to maintain and direct the way the company to move in accordance with corporate goals and programs. The internal control system is used to control all activities undertaken by the company including the grant procedure. The purpose of this study is to evaluate the effectiveness of the internal control system of grant procedures in the Regional Office of the Ministry of Religion Affairs of North Sulawesi Province. In this study the type of data used is qualitative data, while for data sources using primary data and secondary data, and the method of analysis used is descriptive analysis method. Based on the results of the research, it is concluded that the grant procedure in the Regional Office of the Ministry of Religion Affairs of North Sulawesi Province has been effective because it has fulfilled the existing components of internal control.
\end{abstract}

Keywords: Internal Control, Grant Procedures

\section{PENDAHULUAN}

Sistem Pengendalian Internal merupakan suatu sistem usaha atau sistem sosial yang dilakukan perusahaan yang terdiri dari struktur organisasi, metode dan ukuran-ukuran untuk menjaga dan mengarahkan jalan perusahaan agar bergerak sesuai dengan tujuan dan program perusahaan, mendorong efisiensi serta dipatuhinya kebijakan manajemen. Pengendalian internal dirancang untuk memberi suatu keyakinan akan tercapainya tujuan perusahaan yang secara umum dipisahkan dalam tiga jenis, yaitu keefektifan dan efisiensi operasional perusahaan, pelaporan keuangan yang handal, kepatuhan terhadap prosedur dan peraturan yang diberlakukan. Pengendalian internal dalam prosedur pemberian hibah yaitu untuk mengontrol dan memantau prosedur pemberian hibah yang ada di Kantor Wilayah Kementerian Agama Provinsi Sulawesi Utara apakah prosedurnya sudah efektif atau masih terjadi kekeliruan dalam proses pemberian hibah. Pengertian hibah secara umum yaitu setiap penerimaan organisasi pemerintah dalam bentuk uang, barang, jasa dan atau surat berharga yang diperoleh dari pemberi hibah yang tidak perlu dibayar kembali yang berasal dari dalam negeri atau luar negeri. Dengan adanya dana hibah organisasi pemerintah mendapat manfaat secara langsung untuk mendukung tugas dan fungsi untuk kesejahteraan masyarakat bersama. Penerimaan langsung dana hibah oleh Pemerintah Pusat dapat diteruskan kepada Pemda, BUMN dan BUMD.

Hibah bersumber dari APBD dan APBN. APBN memuat rencana penerimaan dan pengeluaran negara selama satu tahun anggaran mulai dari 1 Januari hingga 31 Desember. Perubahan APBN, dan pertanggungjawaban APBN setiap tahun ditetapkan dengan UU. Struktur APBN meliputi pendapatan negara dan hibah, belanja negara, keseimbangan primer, surplus atau defisit anggaran, dan pembiayaan. APBN berfungsi untuk mengatur pengeluaran dan pendapatan negara dalam rangka membiayai pelaksanaan kegiatan pemerintahan dan 
pembangunan, mencapai pertumbuhan ekonomi, meningkatkan pendapatan nasional, mencapai stabilitas perekonomian, dan menentukan arah serta prioritas pembangunan. APBD (Anggaran Pendapatan dan Belanja Daerah) yaitu anggaran tahunan pemerintah daerah di Indonesia yang disetujui oleh Dewan Perwakilan Rakyat Daerah.

Buletin Teknis Standar Akuntansi Pemerintahan Nomor 13 merupakan informasi yang berisi penjelasan teknis akuntansi sebagai pedoman bagi pengguna. Buletin Teknis SAP (Standar Akuntansi Pemerintahan) untuk mengatasi masalah teknis akuntansi dengan menjelaskan secara teknis penerapan PSAP (Pernyataan Standar Akuntansi Pemerintahan) dan IPSAP (Interpretasi Pernyataan Standar Akuntansi Pemerintahan). Buletin Teknis 13 tentang Akuntansi Hibah, pendapatan hibah didefinisikan sebagai penerimaan negara/daerah dalam bentuk devisa, devisa yang dirupiahkan, Rupiah, barang jasa, dan/atau surat berharga yang berasal dari pemerintah negara asing, badan/lembaga asing, badan/lembaga internasional, pemerintah lain, badan/lembaga dalam negeri atau perseorangan yang tidak perlu dibayar kembali.

Prosedur penyaluran hibah di Kantor Wilayah Kementerian Agama Provinsi Sulawesi Utara mengikuti beberapa tahap yaitu tindak lanjut untuk penomoran disetujui oleh Kepala Kantor kemudian tahap selanjutnya pencairan. Dalam praktek pengusulan proposal seringkali mengalami kendala bagi pengusul proposal, pengusul proposal tidak mengetahui tindak lanjut dari proposal tersebut apakah disetujui atau tidak. Ketidak pastian ini bagi pengusul proposal harus menunggu lama, itupun kalau disetujui. Hal ini dikarenakan lambatnya sistem pengendalian internal. Untuk itu perlu melakukan evaluasi efektivitas sistem pengendalian internal dan di pantau sesuai dengan komponen-komponen yang ada dalam pengendalian internal agar keefektifan prosedur pemberian hibah dapat diketahui dengan jelas.

\section{TINJAUAN PUSTAKA}

\subsection{Akuntansi Pemerintahan}

Analisis beserta teknik yang dilakukan pada pengelolaan dana di lembaga-lembaga dan departemen-departemen di bawahnya, pemerintah daerah, BUMN, BUMD, LSM dan yayasan sosial pada proyek kerjasama sektor publik dan swasta (Bastian, 2010:6).

\subsubsection{Standar Akuntansi Pemerintahan}

Prinsip akuntansi yang diterapkan dalam penyusunan dan penyajian laporan keuangan pemerintah, yang terdiri atas Laporan Keuangan Pemerintah Pusat (LKPP) dan Laporan Keuangan Pemerintah Daerah (LKPD) (Tanjung : 2012 dan Agustiawan : 2013)

\subsubsection{Standar Akuntansi Pemerintahan Berbasis Akrual}

Peraturan Pemerintah Nomor 71 Tahun 2010 Pasal 1 ayat (8) menyatakan bahwa standar akuntansi pemerintahan berbasis akrual adalah standar akuntansi pemerintahan yang mengakui pendapatan, beban, aset, utang dan ekuitas dalam laporan finansial, serta mengakui pendapatan, belanja dan pembiayaan dalam pelaksanaan anggaran berdasarkan basis yang ditetapkan dalam APBN/APBD.

SAP (Standar Akuntansi Pemerintahan) berbasis akrual, laporan keuangan yang harus dibuat ada tujuh, yaitu:

1. Laporan Realisasi Anggaran

2. Laporan Perubahan Saldo Anggaran Lebih

3. Laporan Operasional

4. Neraca

5. Laporan Arus Kas

6. Laporan Perubahan Ekuitas

7. Catatan Atas Laporan Keuangan 


\subsubsection{Sistem Akuntansi Pemerintahan}

Peraturan Pemerintah Nomor 71 Tahun 2010 Pasal 1 ayat (11) menyatakan bahwa Sistem Akuntansi Pemerintahan adalah rangkaian sistematik dari prosedur, penyelenggara, peralatan, dan elemen lain untuk mewujudkan fungsi akuntansi sejak menganalisis transaksi sampai dengan laporan keuangan di lingkungan organisasi pemerintah. Pemerintah menyusun Sistem Akuntansi Pemerintahan yang mengacu pada Standar Akuntansi Pemerintahan.

\subsection{Pengendalian Internal}

Pengendalian internal mencakup struktur organisasi, metode dan ukuran yang dikoordinasikan untuk menjaga kekayaan organisasi, mengecek ketelitian dan keandalan data akuntansi, mendorong efisiensi dan mendorong dipatuhinya kebijakan manajamen (Mulyadi, $2013: 163)$

\subsubsection{Unsur-unsur Pengendalian Internal}

Terdapat 5 (lima) unsur pengendalian internal menurut Committee of Sponsoring Organizations of the Treadway Commission (COSO) yang meliputi:

1. Lingkungan Pengendalian (Control Environment)

Perusahaan meliputi sikap para manajemen dan pegawai terhadap pentingnya pengendalian yang ada di organisasi tersebut.

2. Penilaian Risiko (Risk Assestment)

Semua perusahaan mempunyai risiko dalam suatu aktivitas, baik aktivitas yang berkaitan dengan bisnis maupun non bisnis.

3. Aktivitas Pengendalian (Control Activities)

Mengatur proses kegiatan pekerjaan demi menjamin tercapainya tujuan perusahaan dan mencegah, mendeteksi terjadinya kecurangan dan kesalahan.

4. Pemantauan (Monitoring)

Menemukan kekurangan serta meningkatkan efektivitas pengendalian. Pengendalian internal dapat di monitor secara efektif melalui penilaian khusus atau sejalan dengan usaha manajemen.

5. Informasi dan Komunikasi (Information and Communication)

Informasi dan komunikasi merupakan unsur-unsur yang penting dari pengendalian internal perusahaan, diperlukan oleh manajemen untuk pedoman operasional dan menjamin ketaatan dengan pelaporan hukum serta peraturan-peraturan yang berlaku pada perusahaan.

\subsection{Hibah}

Hibah merupakan pemberian dengan mengalihkan hak atas sesuatu kepada orang lain (Kamus Besar Bahasa Indonesia :1999). Menurut New Webster Dictionary and Thesaurus of the English Language "hibah" atau "grant' adalah act of granting the property.

\subsubsection{Mekanisme Pendapatan Hibah Pemerintah Pusat}

Buletin Teknis 13 menjelaskan penerima dibedakan menjadi pemerintah pusat dan pemerintah daerah. Prinsip umum dari pendapatan hibah sesuai dengan Pasal 38 UU No. 1 Tahun 2004 dan tugas pokok dan fungsinya, maka Menteri Keuangan selaku BUN atau pejabat yang diberi kuasa adalah pihak yang dapat menerima hibah baik yang berasal dari dalam negeri maupun luar negeri. Hal ini berkorelasi langsung dengan pencatatannya yang juga dilakukan oleh Menteri Keuangan atau kuasanya untuk melakukan pencatatan atas pendapatan hibah tersebut.

\subsubsection{Prosedur Pengelolaan dan Akuntansi Hibah}

Dalam PMK No. 230PMK05 tahun 2011 digambarkan rangkaian sistem dan prosedur akuntansi dari berbagai transaksi hibah yang saling berkaitan untuk 
menghasilkan output berupa laporan hibah untuk pihak-pihak yang berkepentingan dalam pengelolaan hibah. Beberapa tahapan sistem dan prosedur yang harus dilakukan adalah:

1. Penandatanganan Perjanjian Hibah (Grant Agreement)

Perjanjian Hibah adalah kesepakatan tertulis mengenai Hibah antara Pemerintah dan Pemberi Hibah yang dituangkan dalam dokumen perjanjian pemberian hibah atau dokumen lain yang dipersamakan.

2. Penandatanganan Perjanjian Hibah (Grant Agreement)

Perjanjian Hibah adalah kesepakatan tertulis mengenai Hibah antara Pemerintah dan Pemberi Hibah yang dituangkan dalam dokumen perjanjian pemberian hibah atau dokumen lain yang dipersamakan. Beberapa tahapan yang perlu dilakukan untuk memperoleh nomor register adalah sebagai berikut:

A. Setelah perjanjian hibah ditandatangani oleh KL dan pemberi hibah, Sekretaris Jendral K/L mengajukan surat permohonan nomor register dengan melampirkan:

a) Perjanjian hibah $(\mathrm{PH}) /$ Memorandum of Understanding $(\mathrm{MoU})$ atau dokumen lain yang dipersamakan.

b) Grant Summary atau ringkasan perjanjian hibah dan disbursement plan.

Disbursement plan atau rencana penarikan hibah disajikan per-tahun sampai dengan perjanjian hibah dinyatakan tidak dapat ditarik lagi (closed).

B. Surat balasan (nomor registrasi) dari Direktur Jenderal Pengelolaan Utang Kementerian Keuangan dalam hal ini Direktur Evaluasi, Akuntansi dan Setelmen ditujukan kepada Sekretaris Jenderal K/L atau kepada pihak yang mengajukan permohonan registerasi.

Dalam pengajuan nomor register ke DJPU yang harus diketahui adalah:

A. Pemberian nomor register tidak berdasarkan Negara pemberi hibah tetapi berdasarkan jumlah perjanjian hibah, misalnya: hibah dari World Bank yang diberikan kepada Kementerian/Lembaga sebanyak 5 perjanjian hibah yang berbeda, maka pengajuan nomor registerasi kepada DJPU sebanyak 5 hibah dan akan diberikan 5 nomor register.

B. Pemberian nomor register tidak didasarkan atas bentuk hibah, misalnya dalam satu perjanjian hibah, pemberi hibah akan memberikan hibah berupa uang, barang dan jasa, maka pemberian nomor register hibah tidak didasarkan pada bentuk hibah tersebut.

C. Pemberian nomor register hibah tidak diberikan atas dasar lamanya waktu penarikan hibah, misalnya: dalam satu perjanjian hibah ditentukan akan diterima dalam waktu 5 tahun(multiyears), maka Kementerian/Lembaga tidak perlu untuk mengajukan register setiap tahunnya, cukup satu kali saja untuk satu perjanjian hibah.

Terkait dengan proses pengesahan atas penyerahan aset yang dilakukan K/L kepada pemerintah daerah, tidak perlu dilakukan proses permohonan nomor register.

\subsection{Penelitian terdahulu}

Penelitian yang dilakukan oleh Suryanto, Teguh dan Handayani, Nur 2015 tentang Analisis Pengendalian Intern Pencairan Dana Hibah Pemerintah Daerah Kepada Masyarakat Tahun Anggaran 2013, menyatakan bahwa mekanisme pencairan hibah yang dimulai dari Bendahara Pengeluaran mengajukan Surat Permintaan Pembayaran (SPP) beserta dokumen lainnya kepada pejabat penatausahaan keuangan Satuan Kerja Pengelola Keuangan Daerah (PPK-SKPKD).

\section{METODE PENELITIAN}

\subsection{Jenis Penelitian}

Penelitian ini termasuk pada jenis penelitian kualitatif deskriptif. Sukmadinata (2013) menyatakan bahwa penelitian deskriptif adalah suatu penelitian yang ditujukan untuk 
mendeskripsikan dan menggambarkan fenomena-fenomena yang ada baik fenomena yang bersifat alamiah atau rekayasa manusia. Secara sederhana penelitian deskriptif adalah penelitian yang menjelaskan setiap data yang diperoleh, fenomena yang terjadi dan hasil penelitian di lapangan yang ditemukan, dalam bentuk kata-kata yang menceritakan, mengemukakan dan menggambarkan situasi tersebut yang memiliki makna sesuai dengan hasil penelitian yang dilakukan. Jenis data yang digunakan dalam penelitian ini meliputi data kualitatif dan data kuantitatif. Data kualitatif berupa bahan keterangan dalam bentuk uraian kata-kata dan tidak diukur dalam skala numerik berupa data tentang peraturan pemerintah mengenai perlakuan akuntansi dan pelaporan hibah yang sesuai dengan standar akuntansi pemerintahan, sedangkan data kuantitatif berupa Laporan Keuangan Kantor Wilayah Kementerian Agama Provinsi Sulawesi Utara.

\subsection{Tempat dan Waktu Penelitian}

Penelitian ini dilaksanakan pada Kantor Wilayah Kementerian Agama Provinsi Sulawesi Utara yang bertempat di Jl. 17 Agustus, Kota Manado, Sulawesi Utara. Waktu Penelitian dimulai dari Maret sampai dengan bulan April 2018.

\subsection{Prosedur Penelitian}

Mengidentifikasi masalah, menentukan objek penelitian, penyusunan proposal penelitian, pengumpulan data, menganalisis dan mengolah data, hasil penelitian, membuat kesimpulan dan memberikan saran

\subsection{Metode Pengumpulan Data}

Kuncoro, 2013 data merupakan sekumpulan informasi yang diperlukan untuk mengambil keputusan.

1) Data Kuantitatif

Data yang mengandung angka atau bilangan yang digunakan dalam menjelaskan berbagai gambaran dan peristiwa sehubungan dengan pelaksanaaan penelitian.

2) Data Kualitatif

Data kualitatif merupakan kumpulan data yang bersifat deskriptif menyangkut tanggapan responden.

Penelitian ini, penulis menggunakan data kualitatif sebagai dasar untuk mengevaluasi prosedur pemberian hibah serta faktor-faktor apa saja yang menyebabkan kendala dalam prosedur hibah pada Kantor Wilayah Kementerian Agama Provinsi Sulawesi Utara.

\subsection{Sumber Data}

1. Sumber Primer

Sumber primer adalah sumber data yang secara langsung memberikan data kepada pengumpul data (Sugiyono, 2014:308). Sumber primer ini berupa catatan hasil wawancara yang diperoleh melalui wawancara yang penulis lakukan. Selain itu, penulis juga melakukan observasi lapangan dan mengumpulkan data dalam bentuk catatan tentang situasi dan kejadian di perpustakaan.

2. Sumber Sekunder

Sumber data sekunder ini dapat berupa hasil pengolahan lebih lanjut dari data primer yang disajikan dalam bentuk lain atau dari orang lain (Sugiyono, 2014:131). Data ini digunakan untuk mendukung infomasi dari data primer yang diperoleh baik dari wawancara, maupun dari observasi langsung ke lapangan. Penulis juga menggunakan data sekunder hasil dari studi pustaka. Dalam studi pustaka, penulis membaca literatur-literatur yang dapat menunjang penelitian, yaitu literaturliteratur yang berhubungan dengan penelitian ini.

Sumber data yang digunakan dalam penelitian ini adalah data primer dan sekunder. Data primer berupa data hasil wawancara yang dilakukan kepada Sub Bagian Bimbingan Masyarakat secara langsung. Sedangkan data sekunder berupa informasi-informasi tentang instansi pemerintahan dalam bentuk arsip maupun 
buku dan melalui studi dokumentasi dengan mempelajari berbagai tulisan dalam buku, internet, jurnal, skripsi yang berhubungan dengan penelitian.

\subsubsection{Teknik Pengumpulan Data}

Dalam Penelitian ini, penulis menggunakan beberapa teknik dalam pengumpulan data yaitu:

1. Teknik wawancara

Mengadakan tanya jawab langsung kepada responden atau pihak yang terkait dalam instansi pemerintahan. Metode ini digunakan untuk memperoleh data tentang gambaran umum instansi untuk mengevaluasi prosedur pemberian hibah, serta faktor-faktor apa saja yang menyebabkan kendala dalam prosedur hibah pada Kantor Wilayah Kementerian Agama Provinsi Sulawesi Utara.

2. Teknik dokumentasi

Pengumpulan data yang diperoleh dari catatan-catatan yang dimiliki instansi pemerintah. Teknik ini digunakan untuk memperoleh data tentang gambaran umum perusahaan untuk mengevaluasi prosedur hibah serta faktor-faktor apa saja yang menyebabkan kendala dalam prosedur hibah pada Kantor Wilayah Kementerian Agama Provinsi Sulawesi Utara.

\section{HASIL ANALISIS DAN PEMBAHASAN}

\subsection{Hasil analisis}

4.1.1 Bentuk Hibah pada Kantor Wilayah Kementerian Agama Provinsi Sulawesi Utara

Bentuk hibah pada Kantor Wilayah Kementerian Agama Provinsi Sulawesi Utara dibagi menjadi 2 bentuk yaitu, hibah uang dan hibah barang/jasa.

a.Hibah Uang

Hibah uang merupakan pemberian bantuan dalam bentuk uang kepada lembaga/organisasi masyarakat. Hibah uang pada Kantor Wilayah Kementerian Agama Provinsi Sulawesi Utara diberikan kepada penerima hibah sebanyak satu kali dalam setahun. Contohnya, pada tahun anggaran 2010 penerima hibah sudah mendapatkan bantuan hibah maka pada tahun anggaran 2011 penerima hibah tidak bisa mendapat bantuan hibah, bantuan tersebut akan didapat pada tahun anggaran 2012.

b.Hibah Barang/Jasa

Hibah barang/jasa merupakan pemberian bantuan dalam bentuk barang/jasa kepada lembaga/organisasi masyarakat. Pada Kantor Wilayah Kementerian Agama Provinsi Sulawesi Utara hibah barang yang dimaksud adalah sebagai berikut:

1.Dalam bentuk barang, hibah yang diberikan yaitu, komputer, meja, kursi, dan permainan untuk kelompok bermain (KB) diberikan kepada penerima hibah sebanyak satu kali dalam setahun. Contohnya, pada tahun anggaran 2010 penerima hibah sudah mendapatkan bantuan hibah maka pada tahun anggaran 2011 penerima hibah tidak bisa mendapat bantuan hibah, bantuan tersebut akan didapat pada tahun anggaran 2012.

2.Dalam bentuk jasa, hibah yang diberikan yaitu, tenaga penasehat dalam hal ini mengenai ilmu keagamaan.

\subsubsection{Persyaratan Penerima Bantuan Hibah pada Kantor Wilayah Kementerian Agama Provinsi Sulawesi Utara}

1. Menyerahkan Proposal Bantuan yang sudah diverifikasi oleh PPK dengan melampirkan RAB.

2. Menetapkan Surat Keputusan Penetapan Penerima Bantuan yang disahkan oleh KPA.

3. Melampirkan Legalitas Organisasi Kemasyarakatan Islam dan Lembaga Keagamaan serta Surat Rekomendasi dari Kementerian Agama Kabupaten/Kota. 
4. Memiliki Nomor Pokok Wajib Pajak (NPWP).

5. Melampirkan Anggaran Dasar dan Anggaran Rumah Tangga.

6. Melampirkan Surat Keterangan Domisili.

7. Memiliki rekening bank yang masih aktif, atas nama Organisasi Kemasyarakat Islam dan Lembaga Keagamaan, dibuktikan dengan salinan buku rekening yang telah dilegalisasi oleh pihak bank, dan Surat Referensi dari bank terkait yang menyatakan rekening tersebut dalam keadaan aktif.

8. Memiliki alamat yang jelas serta nomor telepon yang dapat dihubungi untuk mempermudah komunikasi.

9. Menandatangani Surat Perjanjian Kerjasama.

10. Menandatangani Surat Pernyataan Tanggung Jawab Belanja (SPTJB).

11. Menandatangani Surat Pernyataan Tanggung Jawab Belanja Operasional (SPTJBO).

12. Surat Laporan Kemajuan Penyelesaian Pekerjaan.

13. Surat Berita Acara Serah Terima.

14. Melampirkan Surat Keterangan Kebenaran Dokumen.

\subsubsection{Proses Penyaluran Bantuan Hibah BUN}

Pada saat penyaluran bantuan hibah, bantuan tersebut diberikan oleh BUN melalui

KPPN, karena KPPN merupakan kuasa bendahara umum negara yang ditugaskan langsung oleh menteri keuangan selaku bendahara umum negara untuk mengelola anggaran dalam wilayah kerja tertentu. Bantuan hibah yang diberikan tidak disalurkan ke kantor wilayah kementerian agama namun bantuan hibah tersebut langsung disalurkan dari KPPN ke rekening bank atas nama organisasi kemasyarakatan dan lembaga keagamaan. Sebelum penerima hibah menerima bantuan tersebut, penerima hibah harus memasukan proposal permohonan bantuan hibah ke Kantor Wilayah Kementerian Agama Provinsi Sulawesi Utara dan seterusnya akan diproses oleh Kantor Wilayah Kementerian Agama Provinsi Sulawesi Utara untuk dilihat apakah penerima hibah sudah memenuhi semua persyaratan penerimaan hibah yang telah ditetapkan. Jika sudah memenuhi persyaratan, maka Kantor Wilayah Kementerian Agama Provinsi Sulawesi Utara akan melakukan pengajuan Surat Perintah Membayar (SPM) ke KPPN selanjutnya KPPN akan memeriksa semua data dari penerima hibah jika sudah sesuai persyaratan dan telah diterbitkan Surat Perintah Pencairan Dana (SP2D) maka bantuan tersebut akan langsung ditransfer ke nomor rekening penerima hibah yang dilampirkan pada saat pengajuan permohonan bantuan hibah.

\subsubsection{Prosedur Penerimaan Bantuan Hibah Pada Kantor Wilayah Kementerian Agama Provinsi Sulawesi Utara}

Tahap pertama yaitu memasukkan proposal, pada tahap ini penerima hibah wajib memasukkan proposal untuk mengetahui berapa banyak dana atau barang yang akan dihibahkan dari Kantor Wilayah Kementerian Agama Provinsi Sulawesi Utara. Proposal dimasukkan di Sub Bagian Umum untuk penomoran surat. Setelah proposal dimasukkan maka akan ditindak lanjuti oleh Sub Bagian Bimbingan Masyarakat yang akan mempertimbangkan apakah sudah memenuhi persyaratan atau tidak. Jika sudah memenuhi persyaratan maka berkas akan diserahkan kepada Bagian Tata Usaha sesuai dengan tugas dan fungsinya dalam melaksanakan koordinasi urusan keuangan. Kemudian akan disetujui oleh Kepala Kantor. Setelah disetujui, berkas akan diproses oleh Sub Bagian Perencanaan dan Keuangan untuk mengeluarkan Surat Perintah Membayar (SPM) yang akan diserahkan ke KPPN. Setelah itu, KPPN akan mengeluarkan Surat Perintah Pencairan Dana (SP2D). Dana atau barang yang akan dihibahkan oleh Kantor Wilayah Kementerian Agama Provinsi Sulawesi Utara akan dicairkan oleh KPPN. Namun jika yang diminta adalah barang, maka KPPN tetap mencairkan hibah dalam bentuk dana. Barang tersebut akan dikeluarkan oleh Kantor Wilayah Kementerian Agama Provinsi Sulawesi Utara. Dengan kata lain KPPN hanya memberikan dana kemudian Kantor Wilayah Kementerian Agama Provinsi Sulawesi Utara 
yang akan menyalurkan barang tersebut. Diserahkan barang tersebut melalui Berita Acara Serah Terima (BAST) oleh Kepala Kantor Wilayah Kementerian Agama Provinsi Sulawesi Utara.

Jika penerima hibah sudah menerima hibah tersebut maka penerima wajib membuat laporan pertanggung jawaban yang akan diserahkan pada Kantor Wilayah Kementerian Agama Provinsi Sulawesi Utara sebagai bukti bahwa hibah tersebut telah digunakan dengan sebaik-baiknya.

\subsection{Pembahasan}

4.2.1 Evaluasi Efektivitas Sistem Pengendalian Internal Dalam Prosedur Hibah Pada Satuan Kerja Kantor Wilayah Kementerian Agama Provinsi Sulawesi Utara

Sistem Pengendalian Internal dalam prosedur hibah pada Kantor Wilayah Kementerian Agama Provinsi Sulawesi Utara ditinjau berdasarkan lima komponen committee of sponsoring organizations of the treadway commission dari pengendalian internal yaitu sebagai berikut :

1. Lingkungan Pengendalian

Lingkungan pengendalian merupakan salah satu yang mempengaruhi efektfitas sistem pengendalian internal pada suatu organisasi. Faktor-faktor yang berpengaruh terhadap lingkungan pengendalian pada suatu organisasi adalah struktur organisasi, praktik kepersonaliaan dan prosedur yang diterapkan. Lingkungan pengendalian prosedur pemberian hibah pada Kantor Wilayah Kementerian Agama Provinsi Sulawesi Utara dapat dilihat dari struktur organisasi/bagian yang terkait dalam proses pemberian hibah yaitu

a. Sub Bag umum, dimana proposal dimasukkan dan diberikan nomor sebagai bukti permohonan permintaan hibah dari pihak yang bersangkutan.

b. Sub Bag Bimbingan Masyarakat, untuk mempertimbangkan persyaratan dalam mencairkan dana hibah.

c. Bagian Tata Usaha, untuk melihat berkas yang diberikan Sub Bag bimbingan masyarakat dan mengkoordinasi urusan keuangan.

d. Kepala Kantor, untuk persetujuan

e. Sub Bag Perencanaan dan Keuangan, untuk memproses keluarnya Surat Perintah Membayar (SPM).

Proses pengajuan proposal sampai pada persetujuan ditangani oleh beberapa bagian secara terpisah. Hal ini berarti pemberian hibah dilakukan secara selektif sehingga kemungkinan terjadinya pemberian hibah yang fiktif sangat kecil. Kemudian pencairannya dilakukan lewat KPPN. Dengan demikian dapat dikemukakan bahwa sistem pengendalian internal dilihat dari lingkungan pengendalian sudah baik atau bisa dikatakan sudah efektif.

2. Penilaian Risiko

Upaya Kantor Wilayah Kementerian Agama Provinsi Sulawesi Utara dalam meminimalisir terjadinya risiko dapat dilihat dari proses pengajuan proposal sampai pencairan hibah pada Kantor Wilayah Kementerian Agama Provinsi Sulawesi Utara. Dalam prosedur pemberian hibah, kemungkinan terjadi penyelewengan sangat kecil, hal ini dapat dilihat dari prosedur pencairan dananya dilaksanakan langsung di KPPN dan dicairkan melalui rekening pemohon. Hal ini jika dikaitkan dengan konsep pengandalian internal dari segi penilaian resiko, maka dapat dikatakan bahwa prosedur hibah pada Kantor Wilayah Kementerian Agama Provinsi Sulawesi Utara sudah baik atau bisa dikatakan sudah efektif.

3. Aktivitas Pengendalian 
Dilihat dari aktivitas pengendalian proses kegiatan pemberian hibah pada Kantor Wilayah Kementerian Agama Provinsi Sulawesi Utara mengikuti juknis yang dikeluarkan oleh Kantor Wilayah Kementerian Agama Provinsi Sulawesi Utara, dengan juknis tersebut berarti sistem pengendalian internal pemberian hibah pada Kantor Wilayah Kementerian Agama Provinsi Sulawesi Utara relatif baik. Aktivitas pengendalian atas prosedur pemberian hibah dilaksanakan oleh Kepala Kantor Wilayah Kementerian Agama Provinsi Sulawesi Utara selaku pemberi perintah dan penanggung jawab untuk memberikan bantuan hibah. Hal ini dikarenakan Bagian Bimbingan Masyarakat mempunyai tugas untuk melaporkan pelaksanaan tugas yang diperintahkan kepada Kepala Kantor, maka dapat dikatakan bahwa prosedur hibah pada Kantor Wilayah Kementerian Agama Provinsi Sulawesi Utara sudah efektif.

4. Informasi dan Komunikasi

Informasi mengenai hibah harus melewati panduan juknis sebagai acuan khusus yang dilakukan Kantor Wilayah Kementerian Agama Provinsi Sulawesi Utara dalam pemberian hibah. Maka dapat dikatakan bahwa prosedur hibah pada Kantor Wilayah Kementerian Agama Provinsi Sulawesi Utara sudah baik atau efektif dilihat dari telah terpenuhinya persyaratan dalam informasi dan komunikasi tersebut.

5. Pemantauan

Pemantauan terhadap pemberian bantuan hibah pada Kantor Wilayah Kementerian Agama Provinsi Sulawesi Utara dilakukan oleh Kepala Kantor selaku Pimpinan. Pemantauan selanjutnya dilakukan oleh pihak eksternal dimana pihak tersebut akan memeriksa proses pemberian hibah selama satu periode. Pihak eksternal yang dimaksud adalah Inspektorat dan BPK. Jika dikaitkan dengan konsep pengendalian internal dari segi pemantauan yang mensyaratkan harus adanya pelaksanaan monitor yang baik, maka dapat dikatakan bahwa prosedur hibah pada Kantor Wilayah Kementerian Agama Provinsi Sulawesi Utara sudah baik atau efektif dilihat dari telah terlaksanakannya monitor atau pemantauan langsung oleh Kepala Kantor selaku pimpinan dan dari pihak eksternal.

Dilihat dari tahap ke tahap prosedur pemberian hibah pada Kantor Wilayah Kementerian Agama Provinsi Sulawesi Utara mulai dari pemasukan proposal hingga pencairan dana di KPPN sudah berjalan dengan baik. Proposal yang masuk disetiap Sub Bagian diolah dan dipertimbangkan apakah sudah memenuhi persyaratan atau tidak. Namun kekurangan dari Kantor Wilayah Kementerian Agama Provinsi Sulawesi Utara belum menerapkan Standar Operasional Prosedur (SOP) untuk prosedur hibah. Pengendalian Internal terhadap prosedur pemberian hibah di Kantor Wilayah Kementerian Agama Provinsi Sulawesi Utara telah memeuhi syarat berdasarkan telah terpenuhinya lima komponen Committee of Sponsoring Organizations of Threadway Commission (COSO) maka dengan ini prosedur pemberian hibah yang dilakukan oleh Kantor Wilayah Kementerian Agama Provinsi Sulawesi Utara sudah dapat dikatakan efektif.

\section{KESIMPULAN DAN SARAN \\ 5.1 Kesimpulan}

Berdasarkan hasil penelitian dan pembahasan yang telah dilaksanakan pada Kantor Wilayah Kementerian Agama Provinsi Sulawesi Utara dapat diambil kesimpulan sebagai berikut:

1. Kantor Wilayah Kementerian Agama Provinsi Sulawesi Utara telah memenuhi unsurunsur Committee of Sponsoring Organizations of Threadway Commission (COSO) dalam prosedur pemberian hibah, namun di dalam prosedur pemberian hibah yang ada 
di Kantor Wilayah Kementerian Agama Sulawesi Utara belum menerapkan Standar Operasional Prosedur (SOP), maka dengan ini prosedur pemberian hibah yang dilakukan oleh Kantor Wilayah Kementerian Agama Provinsi Sulawesi Utara sudah dapat dikatakan efektif dilihat dari terpenuhinya unsur COSO.

2. Prosedur pemberian bantuan hibah yang ada di Kantor Wilayah Kementerian Agama Provinsi Sulawesi Utara sudah efektif dilihat dari terstrukturnya proses pemberian hibah dari tahap pertama hingga akhir dipantau dan dievaluasi oleh Kepala Kantor Wilayah Kementerian Agama Provinsi Sulawesi Utara.

3. Bentuk hibah yang ada di Kantor Wilayah Kementerian Agama Provinsi Sulawesi Utara adalah seperti dana dan barang. Adapun yang berbentuk jasa seperti tenaga kerja pengajar, sangat minim karena di Kantor Wilayah Kementerian Agama Provinsi Sulawesi Utara hanya berfokuskan ke hibah yang berbentuk dana dan barang. Contoh hibah berbentuk jasa di Kantor Wilayah Kementerian Agama Provinsi Sulawesi Utara seperti guru agama di sekolah-sekolah atau di TK

\subsection{Saran}

Berdasarkan hasil penelitian dan pembahasan yang telah dilaksanakan, adapun saran yang mungkin dapat dipertimbangkan sebagai masukan untuk dilaksanakan oleh Kantor Wilayah Kementerian Agama Provinsi Sulawesi Utara adalah sebagai berikut:

1. Kantor Wilayah Kementerian Agama Provinsi Sulawesi Utara diharapkan untuk tetap mengikuti peraturan yang berlaku jika terjadi perubahan peraturan di masa yang akan datang, agar supaya keefektifan prosedur pemberian hibah tetap dapat ditingkatkan dan dipertahankan.

2. Sebaiknya pihak Kantor Wilayah Kementerian Agama Provinsi Sulawesi Utara, dalam pemberian bantuan hibah harus memperhatikan syarat-syarat bagi penerima hibah, contohnya penerima hibah harus tahu dalam membuat laporan pertanggungjawaban.

3. Kantor Wilayah Kementerian Agama Provinsi Sulawesi Utara sebaiknya membuat Standar Operasional Prosedur (SOP) untuk hibah agar prosedur hibah yang ada di Kantor Wilayah Kementerian Agama Provinsi Sulawesi Utara lebih jelas dan terarah.

\section{DAFTAR PUSTAKA}

Abdul Hafiz Tanjung.2012. Akuntansi Pemerintahan Daerah. Bandung: Alfabeta.

Agustiawan Lasoma, Vicky. 2013. Pengaruh Standar Akuntansi Pemerintah (SAP) Terhadap Kualitas Laporan Keuangan Pemerintah Daerah Pada Dinas Pendapatan Pengelolaan keuangan dan Aset Daerah Kabupaten Gorontalo Utara. Jurnal Vol 1. Universitas Negeri Gorontalo. Gorontalo

Bastian, Indra. 2010. Akuntansi Sektor Publik Suatu Pengantar. Edisi Ketiga. Erlangga. Jakarta.

Buletin Teknis, Penyajian dan Pengungkapan Belanja Pemerintah. Komite Standar Akuntansi Pemerintahan. jakarta 2016

Kamus Besar Bahasa Indonesia Pusat Bahasa. 1999. Hibah. PT Gramedia Pustaka Utama. Jakarta.

Kuncoro, Mudrajat. 2013. Metode Riset Untuk Bisnis dan Ekonomi. Edisi Keempat. Jakarta: Erlangga.

Mulyadi. 2016. Sistem Akuntansi. Edisi 4. Salemba Empat. Jakarta.

Mulyadi. 2013. Sistem Akuntansi. Salemba Empat. Jakarta 
Perdirjen Perbendaharaan Nomor PB-81/PB/2011 tentang Tata cara Pengesahan Hibah Langsung Bentuk Uang dan Penyampaian Memo Pencatatan Hibah Langsung Bentuk Barang/Jasa/Surat Berharga. Jakarta

Peraturan Menteri Keuangan Nomor 40/PMK.05/2009 tentang Sistem Akuntansi Hibah. Jakarta

Peraturan Menteri Keuangan Nomor 230/PMK.05/2011 tentang Sistem Akuntansi Hibah. Jakarta.

Peraturan Menteri Keuangan Nomor 191/PMK.05/2011 tentang Mekanisme Pengelolaan Hibah. Jakarta.

Peraturan Pemerintah Republik Indonesia Nomor 71 Tahun 2010 tentang Standar Akuntansi Pemerintahan. Lembaran Negara Republik Indonesia Tahun 2010 Nomor 47. Jakarta.

Suryanto, Teguh., dan Handayani, Nur. 2015. Analisis Pengendalian Intern Pencairan Dana Hibah Pemerintah Daerah Kepada Masyarakat Tahun Anggaran 2013. Jurnal Sekolah Tinggi Ilmu Ekonomi Indonesia Surabaya Program Studi Akuntansi, Vol. 4, No.3.

Sugiyono. 2014. Metode Penelitian Kuantitatif, Kualitatif dan R\&D. Alfabeta. Bandung.

Sukmadinata. 2013. Metode Penelitian Pendidikan. PT Remaja Rosdakarya. Bandung. Undang-Undang Republik Indonesia Nomor 17 Tahun 2003. Keuangan Negara. 9 Juni 2003. Lembaran Negara Republik Indonesia Tahun 2003. Jakarta. 